University of Nebraska - Lincoln

DigitalCommons@University of Nebraska-Lincoln

Faculty Publications: Department of Teaching, Department of Teaching, Learning and Teacher Learning and Teacher Education

Summer 2008

\title{
Initial Impacts of No Child Left Behind on Elementary Science Education
}

George Griffith,

Lawrence C. Scharmann

Follow this and additional works at: https://digitalcommons.unl.edu/teachlearnfacpub

Part of the Curriculum and Instruction Commons, and the Teacher Education and Professional Development Commons

This Article is brought to you for free and open access by the Department of Teaching, Learning and Teacher Education at DigitalCommons@University of Nebraska - Lincoln. It has been accepted for inclusion in Faculty Publications: Department of Teaching, Learning and Teacher Education by an authorized administrator of DigitalCommons@University of Nebraska - Lincoln. 


\title{
Initial Impacts of No Child Left Behind on Elementary Science Education
}

\author{
George Griffith, Superintendent, Northern Valley USD 212 \\ Lawrence Sharmann, Kansas State University \\ Corresponding author - George Griffith, Superintendent, Northern Valley USD 212, \\ Almena, KS 67622; (785) 202-0563 ; Fax: (785) 669-2263 ; scitcher@hotmail.com
}

\begin{abstract}
This research examines the impact of the No Child Left Behind (NCLB) Act on elementary science education within a Midwestern state possessing strong national education measures. Elementary teachers $(\mathrm{N}=$ 164) responded to an online survey, which included both closed-ended and open-ended questions pertaining to science instruction and changes made in science instruction since the implementation of NCLB. More than half of these teachers indicated they have cut time from science instruction since NCLB became a law. The reason given for this decrease in science education was mainly the need to increase time for math and reading instruction.
\end{abstract}

\section{Introduction}

The president of the National Science Teachers Association (NSTA), Linda Froschauer (2006), stated that "science is not being reformed in our elementary schools because some teachers are directed to omit it" ( $\Phi$ 5). Ultimately, science education has suffered because of demands on schools to emphasize math and reading (Froschauer, 2006; Mundry, 2006). Although Froschauer (2006) did not provide any data to

Published in Journal of Elementary Science Education 20:3 (Summer 2008), pp. 35-48. Copyright (C)2008 Western Illinois University; published by Springer. Used by Permission Manuscript accepted September 5, 2007. 
support her statement, a 2006 report from the Center on Education Policy (CEP) addressed a number of effects of No Child Left Behind (NCLB) legislation. One of the effects presented in the four-year study from the CEP was that schools were providing a "narrower curriculum" as a result of NCLB. The report indicated that

Seventy-one percent of the school districts [they] surveyed reported that they have reduced elementary school instructional time in at least one other subject to make more time for reading and mathematics-the subjects tested for NCLB. In some case study districts, struggling students receive double periods of reading or math or both-sometimes missing certain subjects altogether. (Center on Education Policy [CEP], 2006, p. 2)

A concern about a decrease in science instruction at the elementary level was also expressed during the 2006 meeting of the Council of State Science Supervisors. One of the issues addressed during this discussion was the concern reported by numerous elementary teachers that they were being required to cut time from science and other non-assessed subject areas. It was reported that many of these teachers indicated that their district or school leadership instructed them to focus on teaching math and reading because they were the topics that affect a school's accountability according to Annual Yearly Progress (AYP) set forth in the NCLB Act (Council of State Science Supervisors' roundtable discussion, April 2006). The reported decline in science instructional time was occurring when a need for "the teaching of elementary science has never been greater" (Lee \& Houseal, 2003, p. 39).

A number of factors outside of NCLB have been reported in the recent past to have had a negative influence on the amount of science covered in elementary schools. According to Lee and Houseal (2003), there were already many internal and external factors that resulted in a decrease in adequate elementary science education. They defined the factors in the following way:

The external factors include time, money, supplies, material and equipment, classroom management, dealing with diverse learners and individual differences, and support from colleagues, administrators, and the community. The internal 
factors include content preparation, self-confidence levels, anxiety, attitude, and professional identity toward teaching science. (p. 39)

In addition to these factors, however, individuals associated with science education were beginning to feel the negative impact that NCLB's emphasis on math and reading was having on science education as science educators were being forced to defend their discipline against districts who wanted to spend more time on math and language arts. (Vasquez, Teferi, \& Schicht, 2003)

Thus, although researchers have provided a number of reasons for why the amount of time for elementary science may be limited and compromised (Finson \& Beaver, 1994; Lee \& Houseal, 2003; Plourde, 2002), the CEP has indicated that the changes mandated by NCLB created another factor which seems to exacerbate the problem.

Changes are often difficult under the best of circumstances, but when changes are mandated, their impact can only be more severe. The changes that have occurred resulting in a narrower curriculum may have been attributed to how individual educators, schools, and districts deal with mandated change processes as noted by Fullan (1996). One of the eight lessons about change presented by Fullan was that "you cannot mandate what matters" (p. 496) when attempting to make an educational change. Mandated changes produce difficult circumstances for teachers because they strongly resist reforms imposed on them by an external force, especially if it directly influences what occurs in their classrooms (Kirst, Anhalt, \& Marine, 1997; McAdams, 1997). This resistance may have been a result of education having a history of implementing reforms and interventions that have not been successful because the change agents failed to understand the culture of what they are trying to change (McAdams, 1997). Fullan and Miles (1992) stated they

believe that serious educational reform will never be achieved until there is a significant increase in the number of people-leaders and other participants alike-who have come to internalize and habitually act on basic knowledge of how successful change takes place. (p. 744) 
A problem with a change like NCLB or any other educational reform is that "schools are more likely to implement superficial changes in content, objectives, and structure than changes in culture, role behavior, and conceptions of teaching" (Fullan, 2001, p. 64). These quick, superficial changes (e.g., change in length of day and instructional time per subject) attempted by schools in a time of perceived crisis can ultimately cause a situation to become worse (Fullan \& Miles, 1992). Fullan (1996) proposed that a mandated change could result in consequences that were not intended by the policy. An example of an unintended consequence may be the narrowing of curriculum resulting from the policies set forth in NCLB. The CEP (2006) report continued to discuss the different perspectives of school officials with some viewing the extra time in math and reading as a way to close the achievement gap, while others felt students were having their participation in other subjects and/or activities squelched. In the fall of 2006, the NSTA was making an effort, along with other science organizations, to have science included in AYP when NCLB is reauthorized. Researchers agree that we need a strong science education program in this country, and it has to start at the elementary level. As stated by JoAnn Vasquez (2006), "not since the Soviet Union's launch of the Sputnik satellite-48 years ago-has the need to improve science education in America been as clear and as urgent as it is today" (p. ix).

We have seen many reports (e.g., A Nation at Risk, etc.) indicating problems with education policies and reform issues at the national level that do not necessarily impact individual states. States responding to national-level criticisms sometimes fail to discriminate local or state impacts that may be different from those reported nationally. In a Midwestern state traditionally strong on national education measures, a need existed to determine (1) how elementary science instruction has been affected, (2) how the mandated changes set forth by NCLB have been implemented at the elementary level, (3) if NCLB has added to the previously identified problem of inadequate science education found in many K-6 programs, and (4) if there is a need to include science as a measure of a school's AYP when NCLB is reauthorized. 


\section{The Purpose}

In this study, the researchers attempted to discover what influence NCLB has had on K-6 science education in a Midwestern state. The purposes of this study were to do the following:

- Identify any change in science instruction at the elementary level as a result of NCLB.

- Enhance an understanding of how NCLB may or may not impact elementary science education and what role administration plays in any changes being made.

- Identify any positive or negative effects as a result of state policy implemented in response to NCLB.

- Evaluate the resources available for materials and professional development for elementary science educators.

\section{Research Agenda}

In order to examine the impact, if any, that NCLB has had on science instruction at the elementary level, the researchers chose to collect data from K-6 elementary teachers in a Midwestern state in an attempt to answer the following research questions:

- In what way, if any, has NCLB influenced instructional changes in elementary science education?

- Have administrators required teachers to decrease the amount of time spent on science instruction since the implementation of NCLB? If so, why did they require teachers to make these changes? If not, why?

- Do elementary educators feel they needed to make changes in the amount of time for science instruction since NCLB has been enacted? If so, why did they feel they needed to make these changes? If not, why?

- How does the current amount of time spent on science education compare to the time spent on science education prior to NCLB? 
- How has NCLB influenced how teachers prioritize their school and personal budgets for school supplies and/or professional development?

\section{Design}

The researchers employed a survey methodology using a Web-based instrument. The criteria used for selecting participants for this survey included the following two items: (1) they had to be K-6 teachers, and (2) they must be employed within our state.

\section{Data Collection and Instrumentation}

Data reported upon in this study were collected through an online, voluntary response survey. The researchers developed the survey instrument (see Appendix A) and included the same main research questions and sub-questions. The instrument included demographic and closed-ended initial questions with open-ended follow-up queries. This instrument was distributed to $\mathrm{K}-6$ educators $(\mathrm{N}=475)$ via a Midwestern State Department of Education science listserv and a Midwestern Association of Teachers of Science listserv with reminders being e-mailed five days prior to the survey end date. Responses to the online survey were obtained from 164 teachers, yielding a response rate of $34.5 \%$. The survey was accessible from October 15, 2006, through November 1, 2006. The limitations of this survey included self-reporting by subjects, inability to ask clarification questions (since the survey was anonymous) and being able to ensure a representative sampling of all subgroups.

\section{Data Analysis and Representation}

The data were analyzed using two methods. The data from the closed-ended questions were analyzed collectively by tabulating the raw data and determining the percentage of responses to each question. It was then analyzed based on the demographic responses to experience and size of school district. Next, the researchers analyzed 


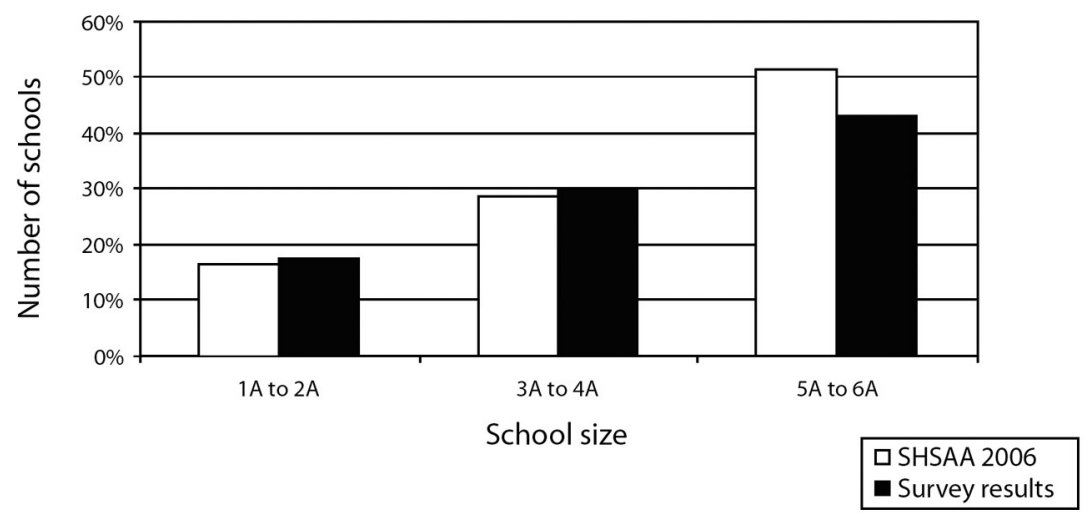

Figure 1. School Size Response Comparison

the teachers' responses to closed-ended questions according to the response given to the question, "Has the amount of time you spend teaching science decreased since the implementation of No Child Left Behind?"

The open-ended questions were analyzed by developing codes based on the methodology presented by Bogdan and Biklen in 1992 (cited in Creswell, 1998). The data were examined for emergent themes and were sorted based on similarities in metaphors, analogies, and concepts. The definitions for the codes are provided in each section of the results.

To determine if the sample of teachers responding to this survey was representative of the schools in the state, a question on the size of the district each teacher taught in was included. As seen in Figure 1, the number of teachers responding in each category based on school size is similar to the percentage of elementary schools in each size category. The size of school was determined by the State High School Athletic Association (SHSAA) and based on the number of students attending the high school served by each school ( $1 \mathrm{~A}$ to $2 \mathrm{~A}=$ small; $3 \mathrm{~A}$ to $4 \mathrm{~A}=$ mid-sized; $5 \mathrm{~A}$ to $6 \mathrm{~A}=$ large).

\section{Results}

\section{Overall Summary}

The researchers initially examined the overall results to determine what percentage of teachers decreased instructional time for science 


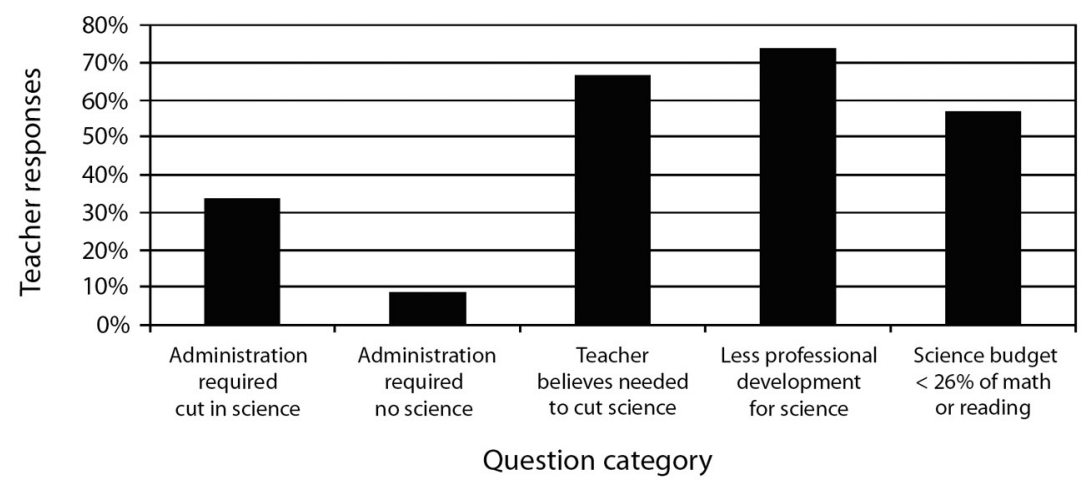

Figure 2. Teachers Who Cut Time from Science Instruction

and what reasons were given for this change. Of the 164 teachers who responded to the survey, 59.1\% indicated they decreased the amount of science instruction in their classrooms since the implementation of NCLB. A summary of the responses this group provided to the follow-up questions is presented in Figure 2. Of the teachers who indicated they decreased science instruction, 71.8\% decreased the amount of science instruction 31 to 90 minutes per week. As a result of decreasing time, $53.6 \%$ of the K- 6 teachers surveyed spent 90 minutes or less per week on science instruction.

One of the teachers who was required to cut instructional time for science $(n=37)$ stated, "We have been directed to spend more time on math and reading because those are the subjects upon which AYP is based. At my grade level, we teach each of those subjects for a minimum of one and a half hours daily. Some children are on 'pull out' for even more instruction in math and reading." Another teacher indicated she was" forced to [cut instructional time in science] in order to increase minutes for math and reading," and yet another stated, "District/State mandates required time for math and reading. Plus, additional time for Tier 2 and 3. With all the benchmarks to cover before progress reports are released and needing to cover materials for them, there is not enough time in the day to get the recommended science time in." These responses summarize the key points made by this subgroup. This subgroup was also asked what reason was given by the administration for requiring them to decrease instructional time for science, and they all provided a similar reason which can be summarized in the following way: cuts were due to the need to improve performance in the assessed content areas. 




Figure 3. Did Not Cut Time for Science Instruction

One teacher in the subgroup who felt they needed to cut time from science ( $n=84)$ stated, "There is an increase in the importance of making sure the students have all the tested standards in math and reading down. This means repeated instruction over the standards. Since science is not tested at this point then it takes a back burner to the other subjects." Another teacher responded by commenting that she "Can't prepare for state tests and do all the other things required of us and still spend as much time on science." The main theme presented by this subgroup was the importance of math and reading in meeting the goals set for the state assessment in these areas. This theme was summarized by one teacher who stated, "Reading is the priority, and then math follows. Reading time is 2.5 hours a day, which does not include any other language arts components such as spelling, grammar, or writing." Some teachers also indicated they felt the time needed to address all content areas and still effectively cover the math and reading standards was not available. In addition to this data, a summary of responses to the follow-up questions by the $40.9 \%$ of teachers who stated they did not decrease instructional time for science are presented in Figure 3.

Of all the teachers who completed the survey, only 83 teachers responded to the question, "Have you ever had to give a grade for science even though you did not spend time teaching or evaluating science material?" Of those who answered this question, $21.7 \%$ indicated they had given a grade without instructing and/ or assessing it. The reasons provided by this subgroup fit into two major groups, which included (1) a grade was required for the grade cards and (2) science 
was covered but not assessed. Of these teachers, $67.9 \%$ fell into the grade was required category.

\section{Additional Comments}

The additional comments provided by the subjects represented the final section to be evaluated and coded. These comments were placed into five different themes which included (1) support for science education, (2) integration, (3) limited curriculum, (4) shortage of resources, and (5) satisfaction.

Of teachers who provided additional comments ( $n=71)$, 36.9\% indicated there was a limited curriculum in their school. A limited curriculum was defined in this study as one that focused the majority of instructional time on math and reading while cutting back on other subject areas. A teacher stated, "We spend far too much time obsessing over test scores in math and reading to the detriment of other subjects that are equally important for a good education," which was a common theme in this group of respondents. Even those who were required to teach more science have made similar statements, with one teacher stating, "We are now required to spend a greater amount of time teaching science, but at the same time, the requirements for what must be learned in math and reading prior to testing increase[s]. No one is really checking on our science teaching, but we are very accountable for the math and reading test scores [so] science always gets lost in the crunch for teaching time." Comments similar to these were provided in most of the open-ended responses in this survey.

There was one group who emphasized the importance of science education, with $\mathbf{2 7 . 1} \%$ of the respondents fitting into the group labeled supportive of science education. The importance of science education was defined in this study as the need for a strong science education in order to benefit the student, society, or both. Some of the support for science was stated in the following way: "I think science is important to individuals as citizens. Many of the decisions we make as consumers and businesses affect the quality of life, we can expect our natural resources to provide in the future. Our state seems to be trying to attract biotechnology firms. The students we have in class now should be the potential employees of these firms." Another teacher stated, "I feel that this area is vitally important to a student's education. We use it daily, just as one would math and English. Technology is leading 
the economy right now and will continue to for quite a while; it [is] our duty as educators to prepare students for their lives ahead. Many of the jobs to yet be created will involve science." Educational leaders and teachers should examine these types of comments before making any curricular changes that will decrease the time set aside for science education.

Other teachers suggested a way to have time to cover the core subjects that were required. Of the teachers, $13.8 \%$ indicated that integration would be a way to meet all the educational needs of their students. Integration was defined in this study as teaching math and reading skills in combination with science or through science based thematic units. Some of these teachers stated, "I have found integration of all subjects helpful in conserving time and teaching more," and "I do a lot of thematic units, which really helps to incorporate this subject into math and reading." These suggestions follow the focus of the State Department of Education's (SDE) 2005 and 2006 summer academies, which provided professional development on how to integrate subject areas.

The next concern addressed through the additional comments section was the shortage of resources. In this study, resources were defined as including time, money, materials, and professional development, with $10.8 \%$ of the comments addressing at least one of these issues. One teacher emphasized that, "There needs to be more resources! Districts need to purchase textbooks and FULL kits. I don't want to be teaching from photocopied worksheets. I want my kids to be reading engaging text, learning from texts, and doing handson experiments!" Another teacher indicated that, "Science education needs more inservice for beginning teachers and teachers who don't feel comfortable teaching it." As demands for more money for education have increased, a focus to provide more funding for science education should be addressed as well.

Although the majority of the additional comments made were critical of how each of the respondent's school was addressing science at the elementary level, there was a group of teachers who demonstrated satisfaction with how science was being addressed in their school. Satisfaction was defined in this study as a teacher feeling his or her school was doing all it needed to meet the science education needs of its students. Just under $11 \%$ of the teachers who provided additional comments indicated they were satisfied with the science education 
in their school. One example of the comments made by these teachers was, "I think that my school does a good job of balancing the time we spend on math and reading with the time we need for science and social studies. I know of other schools in our district that spend a lot less time on science in first grade. From what I have heard, the way they provide science is through nonfiction books they read in reading. I don't agree with this." Another teacher commented that, "Our district has not diminished, at least at my level, the amount of time or emphasis we spend on science." Having a school or district that makes it possible to teach science adequately demonstrates a degree of administrative support for science instruction, which is needed to provide a solid science background for students.

\section{Discussion}

The first research question we wanted to answer was in what way, if any, has NCLB influenced instructional changes in elementary science education in a Midwestern state traditionally reporting strong educational measures? It appears that in an effort to reach the goals set by NCLB, science education is taking a back seat to math and reading instruction in our elementary schools. The large percentage of teachers who indicated they have reduced time for science instruction to focus on math and reading provides evidence for this change. If the United States is ever going to have a citizenry that is scientifically literate, we will need to build a strong foundation at the elementary level that middle school, high school, and college instructors can build upon. As reported by the National Research Council (NRC) (2000), "the abilities from one grade level to the next are very similar but become more complex as the grade level increases" (p. 19). The abilities laid out in the National Science Education Standards "are designed to be developmentally appropriate to the grade level span" (p. 19). In order for students to be able to build on prior knowledge, they need an accumulation of developmentally appropriate knowledge and relevant experiences that must be nurtured over a number of years. This is why elementary school science programs are so important. With the degree of complexity science concepts can engender, the 60 minutes or less a week spent on science instruction reported by $35.9 \%$ of the teachers surveyed seems less than adequate. It appears that many 
schools are dealing with the accountability resulting from NCLB in a way that is detrimental to science education by decreasing the amount of time teachers spend on science instruction. This decrease in science instruction is an example of the "narrowing" of curriculum revealed in the 2006 report from the CEP. This demonstrates how schools can make things worse by implementing superficial changes in curriculum as was discussed by Fullan and Miles (1992). Our question should be, "Who is making these instructional decisions? The administration or the individual teachers?"

Our second research question was, "Have administrators required teachers to make changes in science instruction since the implementation of NCLB? If so, what changes did they require teachers to make?" The answer to the second part of this question was answered by our first research question; science instructional time is being decreased. However, is this change the result of administrative mandates as suggested by Linda Froschauer (2006)? It appears that a number of administrators are imposing this change on their teachers, with a little over one-third of the teachers who decreased science instruction stating it was at the request of a member of their school or district administration. A small percentage of teachers $(7.7 \%)$ who did not decrease time for science stated a member of their administration instructed them to cut time from science. Overall, one in four of the teachers in this study had been asked to decrease instructional time in science, which supports the statements made by Froschaur. Other ways in which administrators have influenced science instruction at the elementary level is by providing less funding for science. Of the teachers surveyed, $50.7 \%$ stated their school provides $25 \%$ or less of the funding provided for math or reading instruction, with only $15 \%$ providing equal funding. Another and probably more critical issue that was influenced by the administration was the amount of professional development in science that was provided for teachers. With $70 \%$ of the teachers receiving less time for professional development in science than they were provided in the areas of math and reading, the evidence showing how science education can help students in math and reading was not made available to these teachers.

The limited amount of professional development in science may help explain why elementary educators indicated they felt the need to make changes in science instruction since NCLB has been enacted. Of all the teachers who responded to the survey, 55.9\% indicated they 
believe they need to cut time from science in order to improve their students' math and reading performance. This belief contradicts the research presented by Michael Klentschy (2006) at the 2006 NSTA national convention. Klentschy reported that inquiry science at the elementary level has been shown to increase student performance in math, reading, and writing even with at-risk students. When disaggregating the data based on those who indicated they cut science with those who did not, it seemed teacher belief in cutting time from science in order to improve math and reading scores was more of a factor than administrative mandates. Of the teachers who cut time from science, $79.3 \%$ of these teachers indicated that they believed they needed to make this change compared to only $18.8 \%$ of those who did not cut time from science. Lee and Houseal (2003) stated that there were crucial internal factors that influenced the amount of time for science instruction, including low self-confidence levels and anxiety towards teaching science. Our research revealed, however, that just under $89 \%$ of the teachers who decreased time for science and $85 \%$ of the teachers who did not decrease time for science claimed they were confident teaching the science concepts associated with their grade level. Based on these responses, we question whether the teachers who were making these changes were doing so either at the request of their administration or because it was easier and less time consuming for teachers than the time needed to develop integrated or thematic lessons.

"NCLB is leaving science behind" was a theme proposed by one of the respondents to this survey. A measure of whether this is occurring would be to look at the amount of time used for science instruction today compared to the amount prior to NCLB being enacted. To make this determination, the researchers examined the amount of time removed from science instruction since NCLB was implemented. The data indicate that roughly 50\% of the teachers who cut time from science removed between 31 and 60 minutes per week, with another nearly 20\% cutting between 61 and 90 minutes per week. These cuts in science instruction will ultimately have a detrimental impact on student science skills as they advance to middle and high school. Based on this information, NCLB currently has had a negative effect on science instruction, which may become a larger problem as AYP targets continue to increase for math and reading. The pressure to spend more time on math and reading will continue to increase as the AYP targets increase, so it would not be unexpected for more instructional time 
to be taken from science, even with science being included as part of a school's accreditation starting in 2008.

\section{Implications and Further Study}

Science is separated from other intellectual activity because it is cumulative in nature requiring individuals to build knowledge layer by layer (Shamos, 1995). This cumulative nature is why it is important for students to have an accumulation of knowledge over a number of years. Our research indicates the time needed to provide the foundation layer of this knowledge is being decreased by the majority of the elementary teachers we surveyed. Will teachers and administrators change this trend before science is removed completely from the elementary grades? Some teachers commented that when science becomes part of the yearly state assessments, they will have to spend more time on it. Since science assessments will only be a part of a school's accreditation and not AYP, the recent levels for science proficiency recommended by our State Board of Education were only set at a maximum $75 \%$ by the year 2014 , with some proposals being as low as $50 \%$. With the state targets being lower than what is expected for math and reading and the Midwestern state's assessments only being performed at three grade levels, it is not unreasonable to expect that only the grades assessing science at the elementary levels will spend more time on science; however, math and reading will still be the main focus at all grade levels. As pressure for students to perform increases, we believe the current trend to remove time from science in order to focus on math and reading will become a greater problem than it currently is. The full impact of these changes is yet to be determined. School leadership and teachers need to understand that more of the same type of instruction is not necessarily the way to fix a complex problem, despite the fact that it may be the quickest and easiest way to show something is being done. Although true school change will not be easy or fast, what it must be is beneficial to the students.

Further study needs to be done to see if this is a national problem. Another issue that should be examined is measuring the impact this decrease in science instruction at the elementary level may have on the achievement gap based on gender and at-risk students. When looking at achievement, we need to measure at the middle and high school 
levels as well as at the elementary level. Finally, it may be prudent to study the ability of students exposed to limited amounts of science to problem solve and/or to apply the math and reading skills to which they were exposed.

\section{References}

Center on Education Policy (CEP). (2006, March). From the capital to the classroom: Year 4 of the No Child Left Behind Act summary and recommendations. Retrieved May 29, 2008, from www.cep-dc.org/data/ global/nidocs/NCLB-Year4Summary.pdf.

Creswell, J. W. (1998). Quality inquiry and research design: Choosing among five traditions. Thousand Oaks, CA: Sage.

Finson, K. D., \& Beaver, J. B. (1994). The status of science education in Illinois scientific literacy target schools, $K-6$ (Report No. SLPN-E70222). Macomb: Western Illinois University, College of Education. (ERIC Document Reproduction Service No. ED389523)

Froschauer, L. (2006, September 8). Should science be included in adequate yearly progress? NSTA Reports. Retrieved May 13, 2008, from www.nsta.org/ main/news/stories/nsta story.php?news story ID $=52550$.

Fullan, M. (1996). Professional culture and educational change. School Psychology Review, 25(4), 496-500.

Fullan, M. (2001). The new meaning of educational change (3rd ed.). New York: Teachers College Press.

Fullan, M., \& Miles, M. (1992). Getting reform right: What works and what doesn't. Phi Delta Kappan, 73(10), 744-753.

Kirst, M., Anhalt, B., \& Marine, R. (1997, March). Politics of education standards. The Elementary School Journal, 97(4), 315-329.

Klentschy, M. (2006, April). Student achievement through active science learning. Paper presented at the National Science Teachers Association annual convention, Anaheim, CA.

Lee, C. A., \& Houseal, A. (2003). Self-efficacy, standards, and benchmarks as factors in teaching elementary school science. Journal of Elementary Science Education 15(1), 37-55.

McAdams, R. (1997). A systems approach to school reform. Phi Delta Kappan, $79(2), 138-143$.

Mundry, S. (2006). No Child Left Behind Act: Implications for science education. In J. Rhoton, \& P. Shane (Eds.), Teaching science in the 21st century (pp. 243255). Arlington, VA: NSTA Press.

National Research Council (NRC). (2000). Inquiry and the national science education standards: A guide for teaching and learning. Washington, DC: National Academy Press. 
Plourde, L. A. (2002). Elementary science education: The influence of student teaching-where it all begins. Education, 123(2), 253-259.

Shamos, M. H. (1995). The myth of scientific literacy. New Brunswick, NJ: Rutgers University Press.

Vasquez, J. A. (2006). Foreword. In J. Rhoton, \& P. Shane (Eds.), Teaching science in the 21st century (pp. ix-x). Arlington, VA: NSTA Press.

Vasquez, J. A., Teferi, M., \& Schicht, W. (2003). Science in the city: Consistently improved achievement in elementary school science results from careful planning and stakeholder inclusion. Science Educator, 12(1), 16-22.

Appendix A follows. 


\section{Appendix A}

Years teaching experience: $0-5 \quad 6-10 \quad 11-15 \quad 16-20 \quad>20$

$\begin{array}{lllllllll}\text { Grade you are presently teaching: } & \mathrm{K} & 1 & 2 & 3 & 4 & 5 & 6\end{array}$

Gender: $\quad$ Male $\quad$ Female

School size: $\quad$ 1-2A $\quad 3-4 \mathrm{~A} \quad 5-6 \mathrm{~A}$

1. What is the amount of time you spend each week teaching science?

o-30 min $31-60 \mathrm{~min} \quad 61-90 \mathrm{~min} \quad 91-120 \mathrm{~min} \quad>120 \mathrm{~min}$

2. Has the amount of time you spend teaching science decreased since the implementation of NCLB (if yes, go to question 3; if no, go to question $5)$ ?

Yes or No

3. If you answered yes to question 2, how much time did you have to remove from teaching science?

o-30 min $\quad 31-60 \mathrm{~min} \quad 61-90 \mathrm{~min} \quad 91-120 \mathrm{~min} \quad>120 \mathrm{~min}$

4. Why did you feel the need to decrease your instructional time for science that you indicated in question 3 ?

5. Have you ever been instructed to not teach science for any reason by a member of your administration?

Yes or No

6. If you answered yes to number 5 , what reason was given for doing this?

7. Have you ever been instructed to decrease the time you spend teaching science by a member of your administration?

Yes or No

8. If you answered yes to number 7 , what reason was given for doing this?

9. Do you believe you need to cut time from science education in order to spend more time with math and reading instruction?

Yes or No

10. Explain your answer to question 9 
11. Compared to the funding your school spends on math and reading, what percentage of funding does your school provide for science?

$<25 \%$ of what is spent on math and reading $26-50 \%$ of what is spent on math and reading $51-75 \%$ of what is spent on math and reading $76-99 \%$ of what is spent on math and reading Equal to math and reading

12. How does what you personally spend on science education supplies and materials compare to what you personally spend on math and reading?

13. Are you provided the same opportunity for professional development in science as you are in math and reading?

Yes or No

14. Are you responsible for teaching the assessed indicators for science? Yes or No

15. Do you feel confident to teach science concepts for the grade you teach?

Yes or No

16. Explain you answer to question 15 .

17. Have you ever had to give a grade for science even though you did not spend time teaching or evaluating science material?

Yes or No

18. If you answered yes to question 17, explain why this happened.

19. Please add any additional comments you feel are important in regards to science education in elementary school. 